\title{
Understanding Attitudes and Beliefs of Young Black Adults towards Covid-19 and Lockdown
}

\author{
M. B. Ramose \\ https://orcid.org/0000-0003-3921-7613 \\ Sefako Makgatho University \\ proframose@outlook.com
}

\author{
M. Sethuntsa \\ https://orcid.org/0000-0002-4096 \\ Sefako Makgatho University \\ Molelekeng.sethuntsa@gmail.com
}

\author{
N. Chako \\ https://orcid.org/0000-0002-38082932 \\ Sefako Makgatho University \\ nzuaky.chako.1125@gmail.com
}

\author{
N. H. Maleka \\ https://orcid.org/0000-0002-5818-0820 \\ Sefako Makgatho University \\ n.h.maleka@gmail.com
}

\section{B. P. Hlafu}

https://orcid.org/0000-0002-5518-7234

Sefako Makgatho University

bphlafu@gmail.com

\author{
C. M. Kekana \\ https://orcid.org/0000-0003-0323-4905 \\ Sefako Makgatho University \\ caromonene@gmail.com
}

\section{Nkomiso}

Tsalwa leri I ndzavisiso wa mavonelo, vutivi, matitwelo na ku pfumela ka vantshwa eka ku pfariwa ka tiko hi kwalaho ka xitsongwa-tsongwana xa Covid19. Xikongomelo xa ndzavisiso lowu iku hoxa xandla - ku suka eka thelo ra tidyondzo ta ximunhu na ku hlanganela ka vanhu - kuya eka ku humelela loku anameke ka ku lwisana na Covid-19. Maendleno ya hina iku hlamusela mahungu ya Covid-19 ku suka eka lava vulavuleke timhaka ta vona, tlhandla ka mbirhi, ku veka erivaleni hiku katsakanya kumbe ha rinwe-ha-rinwe ra mahungu ya vanhu lava va nga va xiphemu xa ndzavisiso lowu. Mavekelo lawa ya le rivaleni ya ta katsa tinxaka to hundza rinwe ta mitirho, xikombiso, ta miehleketo, ta ku hlanganela ka vanhu na ta maehleketelelo. Tsalwa leri ari humesi njheka-njhekisano. Kambe I inhlamuselo ya mahungu yo huma eka

\section{UNISA $\cong$}




\section{Ramose et al}

leswi swi vuriweke. Ndzavisiso, ngopfu-ngopfu wa tidyondzo ta ximunhu no hlanganela ka vanhu awu boheka kuva wunga vi lowu tolovelekeke hikwalaho ko pfariwa ka tiko. Swipimelo swo pfariwa ka tiko hi swona swinga endla leswaku ku langutiwa eka vantshwa va vantima lava humaka eka ndhawu leyi hi kuya hi matimu yinga ya vanhu va ntima ntsena. Hikwalaho ka xivangelo lexi, ndzavisiso lowu wu ve lowunga anamangiku. Nakambe, tsalwa leri ari na xikongomelo xo engetela mavoleno, vutivi na matitwelo lama kumekeke kuva ya ri ya "vantshwa va vantima hinkwavo." Ntsena, I ku hoxa xandla eka ku hlayiseka ka ntirho lowu tiyisisiweke eka ku humelela ka xiyimo xa xisayense lexi tshembisaka.

\section{Abstract}

This essay is an inquiry into the perceptions, knowledge, attitudes and beliefs of Young Black Adults towards Covid-19 and the lockdown. The motive for the inquiry is to make a contribution - from the perspective of the humanities and the social sciences - towards the success of the broad-based fight against Covid19. Our approach is to present the narratives on Covid-19 by those who told their stories and then to present a commentary either per narrative or cumulatively. The commentary will be multidisciplinary; covering, for example, psychology, sociology and philosophy. This essay does not, therefore, present an argument. Instead, it is an interpretative commentary on the narratives. Research, especially in the humanities and the social sciences, was bound to be unusual as well as abnormal because of the lockdown restrictions. The restrictions account for the fact that only Young Black Adults in a specific historical Black township in South Africa were the point of focus. For this reason, the focus is severely limited. Accordingly, the essay bears no intention to extend the perceptions, knowledge beliefs and attitudes found in the area to all Young Black Adults. It is a contribution to the conservation of empirical material for use in propitious scientific conditions.

Keywords: Covid-19; knowledge; attitudes; beliefs; perceptions; behaviour; lockdown; social distance; Young Black Adults; narrative

\section{Introduction}

In December 2019 there was an outbreak of Coronavirus disease (Covid-19) which originated in Wuhan, Hubei Province in China. In January 2020 the World Health Organisation (WHO) declared the outbreak of Covid-19 a public health emergency of international concern. In March 2020, WHO made the assessment and declared Covid19 a pandemic (WHO 2020a).

The Coronavirus is a highly contagious disease, resulting in acute respiratory syndrome (Dryhurst et al. 2020, 1). Le Page and Hamzelou (2020, 8-9) stated that the most common symptoms include fever, dry cough and fatigue, but some may only experience a sore throat or runny nose. Other individuals may not experience any symptoms at all. 


\section{Ramose et al}

In severe cases, some develop difficulty breathing and may ultimately experience organ failure. More than $80 \%$ of cases appear to be mild to moderate.

In South Africa, on 5 March 2020, Dr Zweli Mkhize, Minister of Health, announced in a media briefing the first Covid-19 positive case (National Institute of Communicable diseases [a], March 5, 2020), while the first death was reported on 27 March 2020 (National Institute of Communicable diseases [b], March 27, 2020).

At first, the cases were few and far between and morbidity remained low. However, the number of positive cases has since increased significantly, and the mortality rate also increased. As of 26 September 2020, the total number of positive cases in South Africa was 669 489, the total number of deaths was 16376 and the total number of recoveries was 601818 . The number of tests conducted (both in public and private facilities) was 4128438 (Mkhize 2020). As of 23 September 2020, nearly 1 million people have died from Covid-19 globally (WHO 2020b; Worldometers 2020).

\section{A Special Word on Research during Covid-19}

Under lockdown conditions in South Africa, because of Covid-19, the practice of research was limited and problematical. Research institutions concerned directly with ways and means of dealing with Covid-19 in the medical sphere, were among the few exceptions for whom the practice of research was normal and, even urgent. The humanities and the social sciences were pushed into the background of research because of the official "stay-at-home" regulation; especially at lockdown levels five and four because of measures announced by the government to curb the spread of the virus. The practice of research could not be normal in this situation. This is true of the enquiry reflected in this essay. The abnormality of this "research" is such that it may be regarded as a planned but spontaneous opening of a "talk" as and when the situation permitted. The need for ethical clearance did not arise because the informality of the "talk" secured the anonymity of the talking partners. In "Tsotsitaal" it was just a situation of "go toloka"; just talking (Saal and Fredericks 2005, 247-249). Ethical clearance was also unnecessary because the enquiry was not conducted in the name of or on behalf of a particular private or public institution.

Yet, the input of the humanities and the social sciences was and still is a necessary complement to the medical research into Covid-19. The need for people to understand the obligation to behave in specified ways because of Covid-19 is as important as the need to find a cure for it. The latter belongs to the relevant physical and natural sciences. This essay is presented to satisfy the former need. It was difficult to maintain a balance between obeying the regulations on Covid-19 and actually attempting to understand the perceptions, knowledge, attitudes and beliefs of Young Black Adults towards it. The enquiry was conducted in the Black township of Tembisa, following the media report by Mthethwa (2020) stating that a day after the announcement and implementation of level five lockdown, community members in Tembisa, Alex, Ivory Park and Zandspruit did not comply and many people shared their frustrations and photos of the stated areas. 


\section{Ramose et al}

Relevant questions, such as "Where are the Young Black Adults?" need not have been asked since the pertinent answer was already known by almost everyone, namely "at home." Would we then visit them at their homes pursuant to our curiosity? The answer is "no" because "home and family visits" were prohibited, albeit with a few exceptions such as death in the family. This answer was challenged in practice. In some areas, Young Black Adults could be seen sitting or walking together in groups, sometimes even without masks on. This blatant defiance of the lockdown regulations strengthened the need to understand the perceptions, knowledge, attitudes and beliefs of Young Black Adults concerning Covid-19.

The eruption of the Human Immunodeficiency Virus/Acquired Immune Deficiency Syndrome (HIV/AIDS) was also suffused with attitudinal studies (Home 2005, 190193). One of the things that are common to both HIV/AIDS and Covid-19, is the attitude that these health problems "are not for Blacks" even in the face of actual deaths resulting from them. "Blacks are strong, Blacks do not die from such diseases" is a narrative that gained traction when some institutions like the British Broadcasting Corporation (BBC) expressed surprise that Africa did not experience the many deaths expected from Covid19. Harding (2020) wrote in the BBC news that for months experts had been warning that living conditions in crowded communities in South Africa and beyond were likely to contribute to a rapid spread if the coronavirus. Yet the infection rates have been low and the death rate was lower than that of Britain.

"Blacks are strong" is a psychological problem of refusing to accept the truth that "Blacks do die" from Covid-19. Psychology is called upon to clarify and explain this problem. Does "God" take special care of Blacks by protecting them from heavy losses of life to Covid-19? If this is true, is "God" not sustaining the evidently false conviction that Blacks are strong and do not die from Covid 19? The purpose of these questions is to show that like psychology, the humanities may not stay out of the inquiry into understanding the perceptions, knowledge, attitudes and beliefs of Young Black Adults towards Covid-19.

\section{Method}

Social media was used to corroborate our findings. At times we called colleagues and friends, asking if they were witness to comparable situations in their residential areas. Online discussions were also a complementary means of corroboration. Thus, our local focus does at the same time also speak to what prevailed in the country, but without claiming to be universalisable.

\section{Approach}

"Talks" with the Young Black Adults was one of "the mediums" used to gather information. The youth were not asked to identify themselves. Their anonymity served as a shield protecting them against any charge of violating the lockdown regulations. Their anonymity provided exemption from formalising the "talk" by way of conducting 


\section{Ramose et al}

structured interviews. It also rendered it unnecessary to seek their informed consent to proceed with gathering the information and this exemption provided relief from seeking ethical clearance. However, they were informed that the purpose of the "talk" was to record their individual "talk" in the quest to understand their knowledge, beliefs, perceptions and attitudes towards Covid-19. Thus, the purposes of this essay were: i) to obtain an understanding of the quantity and quality of information the Young Black Adults have about Covid-19; ii) to assess the extent and manner in which they use the information with regard to their attitude and corresponding behaviour towards Covid19; and iii) to explore possibilities for the formulation of guidelines to assist in the prevention of the spread of Covid-19.

\section{“Talk" as an Instrument of Data Collection}

According to Hassen (2016, 1-5), "talk" is a natural data collection instrument where people provide data without being intimidated. Through accessing "talk" we can access the full range of human behaviour, thought, perception, culture and social practice as it naturally appears. The researcher participates in "talk" for the discussion to have a natural flow. The formal nature of an interview is removed in "talk." According to Kabir $(2018,214)$, informal interviewing is typically done as part of the process of observing a social setting of interest. This may be best used in the early stages of the development of an area of inquiry, where there is little literature describing the setting, experience, culture or issue of interest. This understanding of "talk" is applicable to the variety of restrictions imposed by law during the Covid-19 pandemic.

There are many ways to analyse information about participant experiences, and thematic analysis is one such way (Aronson 1994, 1). Different authors and researchers use varying steps to conduct thematic analyses. The version used by Sethuntsa $(2009,58-$ $59 ; 2018,76-78)$ was used to analyse the data gathered. This is where the researcher uses a combination of steps, from different authors, to analyse data. Silverman (1993, quoted in Sethuntsa 2009, 57) supports this approach by stating that with qualitative data analysis, there are no specific rules or formulae for analysing data, except guidelines and procedural suggestions which depend on the researcher's judgment and creativity.

Therefore, for the sake of transparency, the following outlined steps were used to analyse data (Sethuntsa 2009, 58-59; Sethuntsa 2018, 76-78):

- The first step was to transcribe the data and for the authors to familiarise themselves with the data by reading and re-reading the transcripts.

- The second step was to engage with the data by reflecting on what the partners in talking communicated: their thoughts, comments, attitudes, the emotions, beliefs, and perceptions presented. Notes were made on the transcripts regarding anything that appeared significant and of interest. 
- The third step was (based on the previous steps) to present a description of the Young Black Adults' experiences related to the various questions posed during the "talk." The authors identified possible underlying meanings in the "talk" and later added their observations and reflections on the gathered data.

- The fourth step was to identify themes from the data gathered during the "talk." Themes in this enquiry were the experiences, thoughts, beliefs, attitudes, and perceptions that have been very strongly emphasised by Young Black Adults.

- The fifth step was to present an overall description of the identified themes that emerged and to integrate them with the literature reviewed.

\section{Risk Perception}

Risk perception is an important factor in determining whether communities will be motivated to adopt a particular set of behaviours during a pandemic (Floyd, PrenticeDunn, and Rogers 2020, 413). Due to the subjectivity inherent in human perception, it is imperative to consider the cognitive, emotional, social, and cultural differences between individuals and within communities (Dryhurst et al. 2020, 2; Slovic 2010, 198; Van der Linden 2015, 118). Risk has been shown to be influenced by people's experiences, personal values, and confidence in institutions (Rickard 2019, 6). Dryhurst et al. $(2020,5)$ found that having direct personal experience with the virus (i.e., positive diagnosis or close contact) and espousing prosocial, collectivist worldviews, may lead to a greater perception of risk. Individuals without direct personal experience are likely to rely on information disseminated by social media, which has the potential to alter risk perceptions depending on the nature of the media coverage (Oh and Lee 2020,2).

Confronting the common threat of Covid-19 has the potential to unify communities, mobilise resources, and strengthen existing relationships at both the individual and societal levels (Sibley et al. 2020, 620). In contrast, the paradoxical notion of coming together by remaining apart may threaten the mental well-being of individuals with the long-term psychological impact being largely unknown. Voluntary solitude flavoured with a commitment to chastity, such as monastic life, is quite different from suddenly imposed semi-solitude. Each one of these two types of solitude requires its own psychological orientation in order to live life "normally."

It is important for communities to be engaged from the onset of an outbreak to respond, have access to accurate information about what is happening at an individual and collective level within communities, and have a way to get reliable answers to questions (Kickbusch and Reddy 2015, 75-78). As the global death toll continues to rise, it has become increasingly important to investigate public perceptions about the disease, namely, the Severe and Acute Respiratory Syndrome (SARS) and the influence that these perceptions have on human behaviour (Dryhurst et al. 2020, 2; Van Bavel et al. 2020, 465). Based on the above, it has become important to understand popular 
perceptions - in this case among Young Black Adults - to have an understanding of the psychology that is prevalent in their situation.

\section{South Africa's Response to Covid-19}

On 15 March 2020, South Africa's President, Cyril Ramaphosa, declared a national state of disaster and announced a 21-day national lockdown on 23 March 2020 under the Disaster Management Act 2020: Regulations relating to Covid-19: Amendment, Government Notice 846 of (2020). The president periodically outlined the lockdown progression and its terms. People were allowed, initially, to leave their homes only to buy food and seek medical help. Provincial borders were closed and international travel banned, except for the repatriation of foreign nationals and the return of South African citizens from foreign countries. This was done to reduce the rate of infection. A quarantine was also enforced on inbound travellers and returning citizens. On 1 May 2020, the lockdown was lowered to level four; from 1 June 2020 the lockdown was lowered to level three; on 18 August 2020 lockdown was moved to level two; and on 20 September 2020 the lockdown was further lowered to level one (Disaster Management Act 2020: Regulations relating to Covid-19: Amendment, Government Notice 846 of 2020).

In relation to sources of information, a survey conducted by Statistics South Africa (2020) found that the majority of respondents obtained information on current public health measures - such as the washing of hands, how to practise social distancingfrom local, national and international media. Social media (including Facebook and Instagram) was the second most frequently used means of obtaining information on both current public health measures and Covid-19. The internet was also cited as another source of information. In some cases, social media was considered less trustworthy compared to government sources or health workers. Formal health providers, including community health workers and NGOs, were listed as some of the most trusted sources of information but were some of the least cited sources of Covid-19 information (Austrian et al. 2020).

Surveys on the awareness of Covid-19 found that, in South Africa, information about the two main means of transmission of the Covid-19 virus was high. Participants indicated that they were aware that the virus is transmitted through touching surfaces contaminated by the virus, or through having contact with a person infected with the virus (Statistics South Africa 2020). According to the survey conducted by Statistics South Africa (2020) with regard to the lockdown regulation of only going out for essential services, the majority of respondents had gone out for grocery shopping and a few respondents managed not to go out for grocery shopping at all. It would appear that the latter category comprised of those who considered they had sufficient supplies in deep freezers. Also, the possibility to do online shopping was open to those who had the equipment to do so. A somewhat different pattern is observed with regard to going to the pharmacy. The majority of respondents managed not to go out to the pharmacy at all. Fear of becoming infected probably dictated caution with regard to going to the 
pharmacy. Respondents' responses indicated that they adhered to the call not to go out to public meetings, with almost all reporting not attending any public events, for example, church services.

Most of the respondents avoided exposing themselves to the virus by leaving their houses only for procuring essential items. Furthermore, the practice of social distancing when going out was a priority for the majority of the respondents. Regular hand-washing when going out and upon returning was also an important practice to most respondents (Statistics South Africa 2020). Respondents were mostly worried about the possible economic collapse caused by the Covid-19 virus; they were concerned about the health of vulnerable people like elderly family members; the overload of the health system; and about the civil disorder that might result as a consequence of the Covid-19 virus (Statistics South Africa 2020).

\section{Demographics}

It was observed that it was mostly young men who were sitting in groups engaging in different activities such as playing cards and other board games. Very few women were observed on the streets. Therefore, it was mostly men and a few women who engaged in the "talks." The Young Black Adults who engaged in these "talks" were coincidentally individuals who were enrolled in tertiary education, those who had just completed their studies and those looking for jobs, as well as those who were selfemployed-including artists and hair stylists. The specific question concerning the exact ages of the partners in the "talks" was not asked. This was in order to retain the natural situation as far as possible. It was undesirable to proceed by way of a formal interview. The quality of the reasoning of the "talk" partners, together with their physical appearance, suggested that they were approximately 35 years of age and younger.

\section{Information about the Lockdown}

Some Young Black Adults understood that the reason for the lockdown was to control the spread of the Coronavirus. They also believed that South Africa had to do what other countries were doing, namely impose a lockdown and introduce various provisions, especially economic and educational ones, for the survival of the inhabitants.

\section{Need for Freedom and Socialising}

Some understood the importance of the lockdown but needed freedom in the form of breaks. Most indicated that socialising was important for them. They could not stay in the house the whole day in front of a television set. They got bored, and to overcome boredom they needed breaks to socialise. Some shared their frustration that they could not buy alcohol as it was part of socialising. 


\section{Impact on their Livelihoods}

Some reported that the lockdown affected their income. For those who had just completed their tertiary education their chances of getting internship opportunities were minimal. Some shared their frustration at being dependent on their parents for financial support. Some women were worried that the lockdown affected their engagement in gainful employment or small income-generating programmes for their individual and collective survival. They acknowledged receiving the child grant, but considered that it made no significant difference as far as the betterment of their living condition was concerned. Those who were employed before the lockdown wanted to go back to work despite the increasing number of job losses. Some homeowners complained that their tenants could not pay rent any longer. The effect of this was that the homeowners' income was negatively affected. The critical question was whether or not the tenants should be evicted under lockdown conditions. There was thus, on the part of the homeowners, some tension between the enforcement of the law and the exercise of mercy towards the tenants who could not pay their rent.

\section{Struggle to Buy Clothes}

Young women complained that they were not able to buy their infants' clothing. The Government later responded by granting permission to buy clothes, especially for the winter. The permission was burdened with restrictions aimed at preventing the spread of Covid-19.

\section{Impact on Education}

Some reported that due to lockdown, tertiary institutions introduced online learning. The problem with this provision was mainly that they themselves, together with many other Young Black Adults, did not have computers, let alone data, to enable them to participate in online learning. The novelty of online learning suddenly and on a large scale demanded a yet-to-be-developed orientation to learning. Radio lessons on specific subjects were restricted to particular grades. The overall impact of this situation was that their progress in learning was seriously slowed down and delayed.

\section{Lockdown Duration}

Some suggested that the lockdown should have been given a full three months instead of breaking it down in successive months. This would have helped them to deal with the impact and get over it. The staggered announcement of lockdown extensions engendered anxiety and uncertainty. It was not conducive to hope that the situation would be better in the foreseeable future. This had an unsettling psychological impact.

\section{Knowledge of Preventative Measures}

Some mentioned that they were aware that they needed to sanitise, even under their shoes. When they got home, they went through thorough washing before going to bed. Others were concerned that staying home did not help, especially since they were 
allowed to go to the shops where they could be exposed to contaminated surfaces and items.

\section{Information about Covid-19}

Some struggled to understand how a disease that "originated" in China ended up in South Africa. Most did not believe it existed and they reported not taking it seriously. They emphasised that they would believe it when someone they knew got infected. Some believed that it was human made. Others suspected that the Covid-19 death statistics were not correct, as it seemed every death was a Covid-19 death. Women were worried about their children getting infected. Others believed that "Coronavirus is a Chinese disease" and does not affect Black people; only those who travel a lot like the Chinese, Indians and Whites run the risk of being infected. In general, Black people do not have the money to travel around and so they believed that it was unlikely that they would be affected in their station.

\section{Need for Information}

Most Young Black Adults needed information on the testing process. They required information on how many people, if any, were infected in their residential areas. They needed hospital staff to educate the communities about Covid-19. They expected hospitals to provide them with gloves and masks or provide them with information on how to make their own face masks. Some engaged in inquiring if there is a cure for Covid-19. Others asked about the 14-day isolation and quarantine. They were not sure about the difference between a bacterium and a virus.

\section{Contaminated Covid-19 Testing Kits}

Some believed that the test kits from China contained the virus. The virus would then be transmitted during the actual testing. They believed we have resources in South Africa to deal with the threat posed by Covid-19. For example, there are medical schools and also pharmaceutical companies that should be able to produce our own test kits. These beliefs were possibly encouraged and maintained by images on social media and news reports that made claims that Covid-19 test kits contain the virus, implying that getting tested, meant becoming infected (Reuters Staff 2020).

\section{Deployment of Soldiers and Police}

South Africa announced the national lockdown, enforced by the deployment of police and the army in a bid to curtail the spread of Covid-19 (Smith 2020). Some Young Black Adults believed that deploying soldiers and police was wrong and a waste of resources. It made them feel like prisoners in their own homes. Some reported on the dangers of deploying soldiers in the streets of the Black townships. "Soldiers are already killing people." "We are always running as if we stole something." Although the soldiers were deployed country-wide, this is a specific reference to some sections of Tembisa township. They also mentioned that police threatened to beat them and lock them up. 
When they were sitting in groups they split up if they saw the police coming and regrouped when the police left.

\section{Physical Abuse}

Some young men alleged that when they spend a lot of time at home, they experience physical abuse from their parents and partners. This was very interesting, as often in the South African context women report a high incidence of abuse under the rubric of domestic violence.

\section{Consequences of Non-adherence to Lockdown Regulations}

When asked about the consequences of not adhering to the lockdown regulations, they shouted "police brutality!"

\section{Recommendations}

They gave the following recommendations:

- There should be a cure.

- Home testing kits should be provided.

- Taverns should open because when you drink alcohol you will not get Covid19.

- They emphasised that community education from healthcare workers and selfcontrol was the best solution.

\section{Discussion}

This essay sought to explore the perceptions, knowledge, prevailing attitudes and beliefs of South African Young Black Adults towards Covid-19 and the lockdown imposed country-wide. The information gathered during the "talks" indicated that Young Black Adults perceived Covid-19 and the ultimate imposition of the national lockdown as holding some adverse effects on some important areas of their lives. While they understood the risks concerning non-compliance to the lockdown regulations, they still seemed to hold the view that the lockdown was disruptive to their day-to-day lives. This is in slight contrast to the assertion made by Floyd et al. $(2020,413)$ that risk perception is an important factor in determining whether communities will be motivated to adopt a particular set of behaviour during a pandemic. The "talk" partners were observed to have been in violation of the lockdown regulations, even though they understood the risks associated with non-compliance.

Interruption of social interactions was also raised as one of the most pressing concerns. This was evident from the observed behaviours where they were gathered in social groups engaging in social activities such as playing cards and other board games. The "talk" partners seemed to be rather united in the notion that there was a need for implementing personal social interaction instead of staying indoors. This defiance of 


\section{Ramose et al}

lockdown regulations was the expression of solidarity despite the legal consequences that would ensue if they were caught. This confirms the view held by Sibley et al. (2020, 620) that confronting the common threat of Covid-19 has the potential to unify communities and strengthen the existing relationships at both individual and societal levels.

Boredom and lack of alcoholic drinks were also cited as one of the push factors for the engagement in person-to-person social interactions. This raises the question of how they would afford the alcoholic drinks, given their concern about financial constraints. Their livelihoods were significantly impacted. This included partial or total loss of income. The general frustration about the loss of income and restricted employment opportunities, on top of the already ailing South African economy, was identified as a recurring theme.

Females highlighted that what was listed as essential items during the lockdown, excluded what they perceived to be essentials, such as infant clothing. The females acknowledged receiving social grants, but they believed it did not meet their financial needs. The "talk" partners also perceived "going out to get essentials" such as groceries further exposed them to the risk of getting infected.

The total halting of most educational activities was also outlined as problematic. The virtual or online resources for continued teaching and learning were cited as a major stumbling block. The habit of contact learning was still preferred. An added advantage of this was that it cancelled the need to obtain both a computer and costly data for online learning. The change in orientation towards learning, coupled with the additional financial burden at a time of widespread loss of income, were considered as serious stumbling blocks. This created the perception of lockdown as more of a "destructive" than a constructive phenomenon. Given the South African history of unequal education, the disparities between the rich and the poor were once again highlighted.

The deployment of soldiers and police by the government (Government Gazette, 25 March 2020) was perceived as life threatening. Their deployment evoked fear instead of contributing effectively to flattening the curve and ensuring compliance with lockdown regulations.

It was concerning to learn about the alleged physical abuse experienced by young men from their parents or partners, especially when the lockdown regulations obliged them to be home.

The provision of knowledge and information was one of the areas on which emphasis was placed. The general knowledge of lockdown and its regulations was found to be good. Although these regulations were not completely adhered to, they were well known. Activities such as the wearing of masks, hygienic activities and social distancing were literally recited by our "talk" partners. The area that seemed to have been lacking 


\section{Ramose et al}

in terms of information, knowledge and belief was the actual witnessing of a diagnosed person. Our "talk" partners emphasised that they needed to hear about someone known to them having tested positive for Covid-19 for them to confidently believe that indeed the pandemic included South Africa.

Some myths also existed among them, such as one who said: "Covid-19 is a Chinese disease. It does not affect Black people." They excluded people of low socio-economic status from possible future cases of Covid-19 due to the fact that they never travel abroad. Once again, this is a familiar phenomenon, reminding of a time where the eruption of HIV/AIDS was also suffused with attitudinal studies. One of the things that are common to both HIV/AIDS and Covid-19, is the attitude that these diseases "are not for Blacks"; even in the face of actual deaths resulting from them. The belief that it possibly does not exist was concerning, as such beliefs could maintain non-compliance and further strengthen the spread of disease.

Another indication regarding the lack of information on testing kits was the notion that South Africa procured some already contaminated test kits from foreign countries such as China. This defective knowledge created the expectation that the local hospital would provide Personal Protective Equipment (PPE) to the community. On the positive, they were also willing to learn how to make their own masks. The symptoms of Covid-19 were also known, as listed in Le Page and Hamzelou (2020). The internal conflict was evident as on the one hand they did not believe Covid-19 existed, however, on the other they were willing to accept PPE from the hospital or make their own masks.

\section{Conclusion}

The primary purpose of this essay was to provide a narrative towards understanding the perceptions, knowledge, prevailing attitudes and beliefs of Young Black Adults towards Covid-19 in relation to the lockdown regulations imposed by law. The main conclusions are as follows: 1) The majority of the people not adhering to the lockdown regulations were males as compared to their female counterparts; 2) The exposure of males to alleged abuse by their parents and partners; 3 ) The general perception that the national lockdown was an intrusion into peoples' lives; 4) Loss of employment and income leading to restricted socialisation and the disruption of educational activities; 5) Partial knowledge of Covid-19 as an illness; 6) Sufficient knowledge of the lockdown regulations; and 7) Fear evoked by the deployment of soldiers.

The internal conflict observed throughout in relation to the disbelief in the existence of Covid-19, was that the test kits were contaminated. Yet, it was accepted that PPE was a necessity. This paradoxical attitude may not be underestimated, as it could possibly influence adherence or non-adherence to lockdown regulations and could possibly sabotage the fight against flattening the curve. The South African political history and injustices towards "Black people" were again invoked to highlight inequalities in the education system. 


\section{Ramose et al}

\section{References}

Aronson, Jodi. 1994. "A Pragmatic View of Thematic Analysis.” The Qualitative Report 2 (1): 1-3. Accessed November 11, 2006. http://www.nova.edu/ssss/QR/BackIssues/QR21/aronson.html.

Austrian, Karen, Jessie Pinchoff, James B. Tidwell, Corinne White, Timothy Abuya, Beth Kangwana and Rhoune Ochako. 2020. "Covid-19 Related Knowledge, Attitudes, Practices and Needs of Households in Informal Settlements in Nairobi, Kenya." (Preprint). Bull World Health Organ. E-pub: 6 April 2020. Accessed July 18, 2020. https://doi.org/10.2471/BLT.20.260281.Disaster Management Act. 2020. Regulations relating to Covid-19: Amendment, Government Notice 846 of 2020. Accessed March 20, 2020. www.openbylaws.org.za.

Dryhurst, Sarah, Claudia R. Schneider, John Kerr, Alexandra L. J. Freeman, Gabriel Recchia, Anne Marthe van der Bles, David Spiegelhalter, and Sander van der Linden. 2020. "Risk Perceptions of Covid-19 around the World." Journal of Risk Research 1-13. https://doi.org/10.1080/13669877.2020.1758193.

Floyd, Donna, Steven Prentice-Dunn, and Ronald Rogers. 2020. "A Meta-analysis of Research on Protection Motivation Theory.” Journal of Applied Social Psychology 30 (2): 407-429. https://doi.org/10.1111/j.1559-1816.2000.tb02323.x.

Government Gazette, 25 March 2020 . Vol.657 (43148). Accessed March 17, 2020. www.gov.za.

Harding, Andrew. 2020. "Coronavirus in South Africa: Scientists Explore Surprise Theory for Low Death Rate.” British Broadcasting Corporation (BBC) News. Accessed April 18, 2020. www.bbc.com.

Hassen, R. 2016. "Talk"” as a Research Data Collection Tool.” Arts and Social Science Journal Vol. 7: 215. Accessed April 18, 2020. https://www.omicsonline.org.

Home, Felicity, June. 2005. "Yesterday, AIDS and Structural Violence in South Africa." Communicatio: South African Journal for Communication Theory and Research 31 (2): 172-197. https://doi.org/10.1080/02500160508538001.

Kabir, Syed Muhammad Sajjad. 2018. "Basic Guidelines for Research.” Bangladesh: Book Zone Publication. Accessed April 18, 2020. https://researchgate.net. https://doi.org/10.1177/1757975915606833.

Kickbusch, I., and K. S. Reddy. 2015. "Community Matters: Why Outbreak Responses Need to Integrate Health Promotion." Global Health Promotion 23 (1): 75-78. Accessed April 20, 2020. www.ncbi.nlm.nih.gov. https://doi.org/10.1177/1757975915606833.

Le Page, Michael, and Jessica Hamzelou. 2020. "What you Need to Know." New Scientist 3272 (3): 8-9. Accessed April 20, 2020. https://doi.org/10.1016/S0262-4079(20)30475-9. 


\section{Ramose et al}

Mkhize, Z. 2020. Media release, 24 July 2020.

Mthethwa, Thandeka. 2020. "Twitter Reacts to Tembisa, Alex, Ivory Park, Zandspruit not adhering to lockdown rules." Midrand Reporter. Accessed April 12, 2020. https://midrandreporter.co.za.

National Institute of Communicable diseases (a). 2020. "First Case of Covid-19 Coronavirus Reported in SA.” March 5, 2020. www.nicd.ac.za.

National Institute of Communicable diseases (b). 2020. “Covid-19 Updates.” March 27, 2020. www.nicd.ac.za.

Oh, Sang-Hwan, and Lee, Sang- Yoon. 2020. "The Effects of Social Media Use on Preventative Behaviours during Infectious Disease Outbreaks: The Mediating Role of Selfrelevant Emotions and Public Risk Perception." Health Communications. https://doi.org/10.1080/10410236.2020.1724639.

Reuters Staff. 2020. "Fact Check: Contaminated CDC Covid-19 Test Kits Recalled and Did not Spread the Virus.” Accessed April 25, 2021. https://www.reuters.com.

Rickard, Laura N. 2019. "Pragmatic and (or) Constitutive. On the Foundations of Contemporary Risk Communication Research.” Risk Analysis 41 (3): 466-479. https://doi.org/10.1111/risa.13415.

Saal, E. O., and C. R Fredericks. 2005. "The Persuasive Effect of Tsotsitaal in HIV/AIDS material." Communicatio: South African Journal for Communication Theory and Research 31 (2): 245-272. https://doi.org.10.1080/02500160508538005.

Sethuntsa, M. 2009. "Being a Young Adult on a Haemodialysis Treatment Program: A Qualitative Study.” Unpublished master's dissertation. University of Limpopo, MEDUNSA Campus, Pretoria.

Sethuntsa, M. 2018. "The Development of a Therapeutic Approach for the Treatment of Individuals with Prader Willi Syndrome and their Primary Caregivers." Unpublished Doctoral thesis. University of South Africa, Pretoria.

Sibley, Chris G., Lara M. Greaves, Nicole Satherley, Marc S. Wilson, Nickola C. Overall, Carol H. J. Lee, and Petar Milojev. 2020. "Effects of the Covid-19 Pandemic and Nationwide Lockdown on Trust, Attitudes toward Government, and Well-being." American Psychologist 75 (5): 618-630. Accessed March 20, 2020. https://doi.org/10.1037/amp0000662.

Slovic, P. 2010. The Feeling of Risk: New Perspectives on Risk Perception. New York: Routledge.

Smith, E. 2020. "South Africa Deploys Police and Army to Enforce 3-week Coronavirus Lockdown." www.cnbc.com. 
Statistics South Africa. 2020. "Behavioural and Health Impacts of Covid-19 Pandemic in South Africa.” Accessed May 25, 2020. http://www.statssa.gov.za.

Van Bavel, Jay J., Katherine Baicker, Paulo S. Boggio, Valerio Capraro, Aleksandra Cichocka, Mina Cikara, and Molly J. Crockett. 2020. "Using Social and Behavioural Science to Support Covid-19 Pandemic Response." Nature Human Behaviour 4: 460-471. Accessed April 27, 2020. https://doi.org/10.31234/osf.io/y38m9.

Van der Linden, Sander. 2015. "The Social-psychological Determinants of Climate Change Risk Perceptions: Towards a Comprehensive Model.” Journal of Environmental Psychology 41 112-124. https://doi:10.1016/j.jenvp.2014.11.012.

World Health Organisation. 2020a. "WHO Coronavirus Disease (Covid-19) Dashboard." Accessed September 23, 2020. https://covid19.who.int/.

World Health Organisation. 2020b. "Mental Health and Psychological Considerations during the Covid-19 Outbreak." WHO/2019-nCoV/MentalHealth/2020.1.

Worldometers. 2020. “Covid-19 Coronavirus Pandemic.” Accessed September 23, 2020. https://www.worldometers.info/coronavirus/\#countries. 